\title{
Production of a modified peptide clavanin in Pichia pastoris: cloning, expression, purification and in vitro activities
}

\author{
Kelly Cristina Mulder ${ }^{1}$, Loiane Alves de Lima ${ }^{1}$, Priscilla Santos Aguiar², Fábio Correa Carneiro², \\ Octávio Luiz Franco ${ }^{1,3}$, Simoni Campos Dias ${ }^{1}$ and Nádia Skorupa Parachin ${ }^{1,2^{*}}$
}

\begin{abstract}
Antimicrobial peptides are one of the most promising peptide-based drugs due to their enormous potential as novel biopharmaceuticals in both human and animal industries. In order to develop strategies to over produce such molecules, heterologous production of a modified version of clavanin A, here named clavanin MO (clavMO), was successfully achieved in the methylothopic yeast Pichia pastoris. ClavMO was fused to thioredoxin as a carrier protein and the construction was tested using two promoters, $\mathrm{P}_{\mathrm{AOX} 1}$ and $\mathrm{P}_{\text {GAP, }}$ based on either induced or constitutive expression systems, respectively. After growth in $5 \mathrm{~L}$ Bioreactor, clavMO-thio was recovered and purified through size exclusion chromatography. Our findings show that both constitutive and inducible expression systems produce active clavMO fused to thioredoxin against both Gram-negative Klebsiella pneumoniae and Gram-positive Staphylococcus aureus microorganisms.
\end{abstract}

Keywords: Heterologous expression, Antimicrobial peptide, Pichia pastoris, Clavanin

\section{Introduction}

Antimicrobial peptides (AMPs) are one of the most promising peptide-based drugs due to their enormous potential as novel biopharmaceutical compounds for the human and animal health industries as well as for their application in agriculture (Agyei and Danquah 2011; Mulder et al. 2013a; Silva et al. 2011a). The increase in interest over these molecules has driven researchers to explore alternatives to chemical synthesis for its largescale production. The production of AMPs using heterologous systems has many advantages, such as allowing post-translational modification and permitting researchers to develop the best genetic strategy to increase its production, and most importantly, there is an extensive flexibility in microbial systems to be modified and scaleup (Mulder et al. 2013b). The heterologous expression of

\footnotetext{
*Correspondence: nadiasp@unb.br

${ }^{2}$ Grupo Engenharia de Biocatalisadores, Departamento de Biologia Celular, Instituto de Ciências Biológicas, Universidade de Brasília, Brasília, DF CEP 70.790-900, Brazil

Full list of author information is available at the end of the article
}

AMPs has been reported to be successfully performed in diverse organisms such as bacteria, plants and yeast (Parachin et al. 2012).

Among these organisms, the methylotrophic yeast Pichia pastoris has been a promising candidate for the heterologous production of AMPs. It has been used for the production of AMPs derived from different sources such as humans (Hong et al. 2007; Kim et al. 2009), mammals (Tang et al. 2012; Zhao and Cao 2012), plants (Cabral et al. 2003; Kant et al. 2009), bacteria (Basanta et al. 2010; Jimenez et al. 2014) and fungi (Varnai et al. 2014; Viragh et al. 2014). From its initial usage in the early 1970s, throughout its complete genome sequence (De Schutter et al. 2009; Mattanovich et al. 2009), to today, P. pastoris has become one of the most extensively studied yeasts and presents a versatile system for the production of heterologous proteins (Ahmad et al. 2014). The most common expression vectors use a genetic construction based on either alcohol oxidase I (AOX1) or glyceraldehyde-3-phosphate dehydrogenase (GAP) promoters, named $\mathrm{P}_{\mathrm{AOX} 1}$ and $\mathrm{P}_{\mathrm{GAP}}$, respectively (Ellis et al. 1985; Waterham et al. 1997). $P_{\text {AOX1 }}$ is a potent and tightly

\section{Springer}


regulated methanol-inducible promoter; therefore it allows for the controlled expression of foreign proteins, especially when they are toxic to the host. $\mathrm{P}_{\mathrm{GAP}}$ is constitutive, and one of its reported advantages is that it simplifies cultivation by avoiding the addition of methanol as a carbon source (Zhang et al. 2009). For instance, human cathelicidin (hCAP18) (Hong et al. 2007) and corn defensin (PDC1) (Kant et al. 2009) have been expressed in $P$. pastoris using a constitutive promoter system. On the other hand, many AMPs have been produced using the AOX1 promoter system reaching over $1 \mathrm{~g} \mathrm{~g}^{-1}$ of dry cell weight (DCW), as was recently reviewed (Parachin et al. 2012).

The AMP used in this work was clavanin MO (clavMO) (Silva et al. 2011b), a synthetic variant of amphipathic alpha-helical peptide clavanin A (clavA). ClavA was first isolated from hemocytes of the tunicate Styela clava. The peptide clavA presents, among its 23 residues, strategically placed histidine residues which provide its $\mathrm{pH}$ dependent antimicrobial activity, as well as glycine and phenylalanine residues which confer to this peptide a relative conformational flexibility and hydrophobicity, thus facilitating its insertion into the target membrane (van Kan et al. 2003b). ClavMO is 5 amino acid residues longer than clavA, and it has been shown to have higher antibacterial activity against both Gram-negative Klebsiella pneumoniae and Gram-positive Staphylococcus aureus. Furthermore, clavMO has also presented immunomodulatory, antitumor and antiviral activities (Silva et al. 2011b).

Due to its high potential as a new antimicrobial peptide, a large amount of clavMO is currently required for the production of different drug-delivery systems. Therefore, the aim of this study was to establish a system for largescale production of heterologous clavMO in P. pastoris.
For that, two promoters, $\mathrm{P}_{\mathrm{AOX} 1}$ and $\mathrm{P}_{\mathrm{GAP}}$ were tested based on two expression systems, induced and constitutive, respectively. ClavMO was fused to thioredoxin as a carrier protein, chosen for its properties of increasing both stability and solubility of heterologous proteins (Esposito and Chatterjee 2006). Our findings show that the induced system produces active clavMO against the microorganisms K. pneumoniae and S. aureus.

\section{Materials and methods}

\section{Strains and plasmids}

Bacterial strains and plasmids used in this work are presented in Table 1 . The strains were grown at $37^{\circ} \mathrm{C}$ in Luria broth medium $(0.5 \%$ Yeast extract, $1 \%$ Peptone and $1 \%$ Sodium Chloride), and the yeast strains were grown at $28^{\circ} \mathrm{C}$ in either YPD $(0.5 \%$ Yeast extract, $1 \%$ Peptone and $2 \%$ Dextrose) or BMGY media (2\% Peptone, $1 \%$ Yeast extract, $100 \mathrm{mM}$ Potassium phosphate $\mathrm{pH}$ 6, 1.34\% Yeast Nitrogen Base (w/o AA), $0.4 \mu \mathrm{g} / \mathrm{mL}$ Biotin, 1\% Glycerol). When necessary, the media were supplemented with the appropriate antibiotics (ampicillin for Escherichia coli cultivations at $100 \mu \mathrm{g} / \mathrm{mL}$, and zeocin for P. pastoris cultivation at $100 \mu \mathrm{g} / \mathrm{mL}$ ). The gene containing the carrier protein thioredoxin fused to the peptide clavMO was cloned into both expression vectors pPICZ $\alpha \mathrm{A}$ and pGAPZ $\alpha \mathrm{B}$, under the methanol-inducible $\mathrm{P}_{\mathrm{AOX} 1}$ promoter and the constitutive $\mathrm{P}_{\mathrm{GAP}}$ promoter, respectively.

\section{Cloning}

The thio-clavMO gene sequence was synthesized by Epoch Life Science (Additional file 1: Figure S1). To clone the gene into both plasmids pPICZ $\alpha \mathrm{A}$ and pGAPZ $\alpha \mathrm{B}$, the restriction sites EcoRI and $S a c I I$ were used, resulting in the expression vectors $\mathrm{pPICZ} \alpha \mathrm{A}$-clavMO and $\mathrm{pGAPZ} \alpha \mathrm{B}-$ clavMO (Figure 1; Table 1). Both plasmids were firstly

Table 1 Strain and plasmids used in this work

\begin{tabular}{|c|c|c|}
\hline Strain and plasmids & Genotype & Reference \\
\hline \multicolumn{3}{|l|}{ Strains } \\
\hline \multicolumn{3}{|l|}{ Ecoli } \\
\hline XL1-Blue & $\begin{array}{l}\left.\text { EndA1 gyrA96(nal }{ }^{R}\right) \text { thi-1 recA1 relA1 lac glnV44 } \\
F^{\prime}\left[\because: \operatorname{Tn} 10 \text { proAB }^{+} \text {lacl }^{q} \Delta\left(\text { lacZ)M15] hsdR17( } r_{K}^{-} \mathrm{m}_{\mathrm{K}}^{+}\right)\right.\end{array}$ & Stratagene \\
\hline \multicolumn{3}{|l|}{ P.pastoris } \\
\hline X33 & Wild type & \\
\hline X33/pPICZ $\alpha A-c l a v M O$ & X33 transformed with the plasmid pPICZ $\alpha A$-clavMO & This work \\
\hline X33/pGAPZaB-clavMO & X33 transformed with the plasmid pGAPZ $\alpha$ B-clavMO & This work \\
\hline \multicolumn{3}{|l|}{ Plasmids } \\
\hline $\mathrm{pPICZ} \alpha \mathrm{A}$ & Fator- $\alpha$ as secretion signal, AOX1 promotor, ble ${ }^{r}$ & \\
\hline $\mathrm{pGAPZ} \alpha \mathrm{B}$ & Fator- $\alpha$ as secretion signal, $P_{\text {GAP }}$ promotor, ble ${ }^{r}$ & \\
\hline pPICZ $\alpha A-c l a v M O$ & pPICZ $\alpha A$ with the gene coding for the cassette thioredoxin-clavanin MO & This work \\
\hline pGAPZ $\alpha$ B-clavMO & pGAPZ $\alpha B$ with the gene coding for the cassette thioredoxin-clavanin MO & This work \\
\hline
\end{tabular}




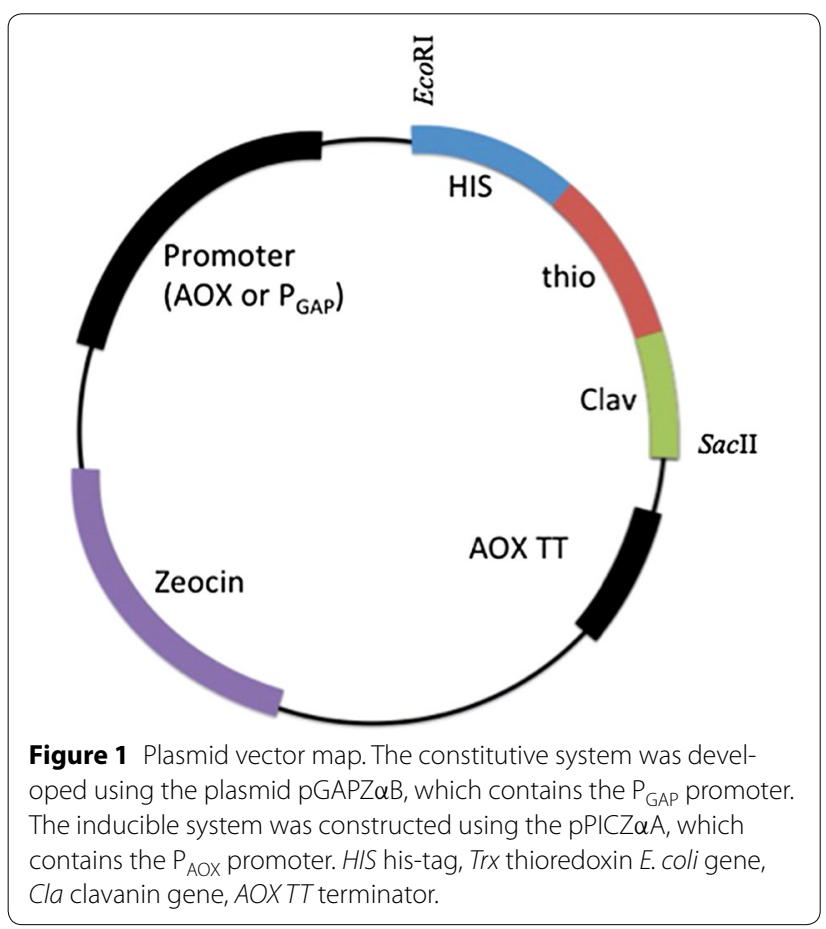

transformed into E. coli XL1-Blue strains and sequenced to confirm the insertion of the expression cassette.

\section{Yeast transformation}

The vectors whose constructions were confirmed by sequencing were inserted into the $P$. pastoris $\mathrm{X}-33$ strain using the electroporation method as described by Invitrogen $^{\mathrm{TM}}$. Briefly, cells of the X-33 strain were grown in solid YPD at $28^{\circ} \mathrm{C}$ for $2-3$ days. A single colony was then grown in $5 \mathrm{~mL}$ of YPD overnight at $30^{\circ} \mathrm{C}$ at $250 \mathrm{rpm} .0 .1$ to $0.5 \mathrm{~mL}$ of this culture was inoculated into $100 \mathrm{~mL}$ of YPD and grown at $30^{\circ} \mathrm{C}$ at $250 \mathrm{rpm}$ until an $\mathrm{OD}_{600}$ of $1.3-1.5$ was reached. The cells were centrifuged at $1,500 \mathrm{~g}$ for $5 \mathrm{~min}$ and washed three times with ice-cold distilled water and then resuspended in $1 \mathrm{M}$ cold sorbitol. Plasmids to be inserted in $P$. pastoris were linearized with $A v r I I$ and BglII for pGAP and pPIC, respectively. About $10 \mu \mathrm{g}$ of linearized DNA was added to $80 \mu \mathrm{L}$ of competent cells and $320 \mu \mathrm{L}$ of $1.0 \mathrm{M}$ sorbitol. Electrical shock using $0.2 \mathrm{~cm}$ cuvette was performed using Gene Pulser II (Biorad). After electric shock, $1 \mathrm{~mL}$ of $1 \mathrm{M}$ cold sorbitol was added to the cells followed by incubation at $30^{\circ} \mathrm{C}$. After $1 \mathrm{~h}$ of incubation, cells were plated in solid YPD medium supplemented with zeocin $100 \mu \mathrm{g} / \mathrm{mL}$ and stored at $28^{\circ} \mathrm{C}$ for $2-3$ days.

\section{Evaluation of clavMO production}

In order to evaluate the production of clavMO in both plasmids, a single colony from each X33/
pPICZ $\alpha$ A-clavMO and X33/pGAPZ $\alpha$ B-clavMO (Table 1) was inoculated into YPD medium at $28^{\circ} \mathrm{C}$ and cultivated overnight at $200 \mathrm{rpm}$ of agitation. Both strains were inoculated in $100 \mathrm{~mL}$ BMGY to reach an $\mathrm{OD}_{600}$ of 0.2 and grew for $96 \mathrm{~h}$. Samples were collected at times 0, 24, 48, $70 \mathrm{~h}$. The pPICZ $\alpha \mathrm{A}$-clavMO strain was induced every $24 \mathrm{~h}$ with methanol $100 \%$ to a final concentration of $0.5 \%$ in order to induce the gene encoding for clavMO cloned under the AOX1 promoter.

\section{Protein quantification, SDS-PAGE and immunoblot assays}

Protein quantification was performed by using QubitInvitrogen $^{\mathrm{TM}}$ according to manufacturer's instructions. For the Western blot and SDS-PAGE experiments, $150 \mu \mathrm{g} / \mathrm{mL}$ of protein from cultured supernatant was collected by the TCA (trichloroacetic acid) precipitation method using TCA at $75 \%$. The pellet was washed twice with ice-cold acetone and dissolved in $25 \mu \mathrm{L} 3 \times$ Laemmli buffer (Laemmli 1970), boiled for $10 \mathrm{~min}$, centrifuged briefly and loaded onto an SDS-PAGE gel using protein molecular weight (Thermo Scientific ${ }^{\mathrm{TM}}$ ). SDSPAGE was silver stained as previously described (Blum et al. 1987). In order to detect proteins, the protein samples were first separated by SDS-PAGE and then transferred under semi-dry conditions onto a nitrocellulose membrane using electroblotting (Towbin et al. 1979). The electrophoretic transfer of proteins was performed in the Trans-Blot SD (Biorad) and carried out for $15 \mathrm{~min}$ at $13 \mathrm{~V}, 3 \mathrm{~A}$ and $300 \mathrm{~mA}$ using Blotting buffer $(3 \mathrm{~g}$ Tris, $14 \mathrm{~g}$ glycine, $20 \%(\mathrm{v} / \mathrm{v})$ methanol, $0.1 \%(\mathrm{w} / \mathrm{v}) \mathrm{SDS}$ ). After transference, membrane blocking was achieved by incubation in AP-T buffer $(1 \mathrm{M}$ Tris/ $/ \mathrm{HCl} \mathrm{pH} \mathrm{7.4,1} \mathrm{M} \mathrm{NaCl,}$ $25 \mathrm{mM} \mathrm{MgCl}, 0.03 \%(\mathrm{v} / \mathrm{v})$ Tween 20) containing 5\% $(\mathrm{w} / \mathrm{v})$ milk powder. The following steps were then carried out only in AP-T buffer. The procedure for detection of labeled proteins was performed using polyclonal antibodies against thioredoxin $(1: 5,000)$ and revealed using $\mathrm{BCIP} / \mathrm{NBT}$ solution, according to the manufacturer's protocol.

\section{Growth of X-33 pPicZ-clavMO in $5 \mathrm{~L}$ Bioreactor}

The strain X-33/pPic-clavMO was grown in a $5 \mathrm{~L}$ bioreactor (Bio Flo115, New Brunswick). For cultivation in the bioreactor, BMGY media was used containing $40 \mathrm{~g} \mathrm{l}^{-1}$ glycerol. Pre-growth was performed in $100 \mathrm{~mL}$ BMGY shake flasks for $30 \mathrm{~h}$. The cells were centrifuged and inoculated in the bioreactor to reach an initial $\mathrm{OD}_{600}$ of 0.5 . Glycerol was used for $24 \mathrm{~h}$ of growth, after which methanol was fed into the bioreactor for a final concentration of $0.5 \%$ every $12 \mathrm{~h}$ up to $72 \mathrm{~h}$. At the end of the fermentation, $5 \mathrm{~L}$ culture medium was centrifuged at $10,000 \mathrm{rpm}$ for $10 \mathrm{~min}$. The supernatant was concentrated 10-fold using Quickstand (GE Healthcare Life Sciences) by 
diafiltration using hollow fiber cartridge with a cut-off of 3,000 NMWC.

\section{Peptide isolation}

Concentrated supernatant from the culture of the strain $\mathrm{X}-33 / \mathrm{pPic}$-clavMO containing $5 \mathrm{mg} / \mathrm{mL}$ of protein extract was lyophilized and injected into a size exclusion chromatography Äkta purifier (GE Healthcare). The column utilized was the Hiload ${ }^{\mathrm{TM}} 16 / 60$ Superdex $^{\mathrm{TM}} 75$ prep grade column (GE Healthcare). This was equilibrated with filtered and degassed water MilliQ at room temperature. The flow rate utilized was $0.8 \mathrm{~mL} / \mathrm{min}$. Fractions were eluted with $5 \mathrm{~mL}$ volumes, totaling 22 fractions. These were monitored at 216 and $280 \mathrm{~nm}$ for $270 \mathrm{~min}$. The fractions from 16 to 22 were lyophilized and used for further antibacterial assays.

\section{Antibacterial assays}

The antibacterial assays were carried out by microdilution assay using an Elisa reader for 96-well microplates (Biotek, USA). Microdilution assays were performed according to the standards of the CLSI (Clinical Laboratory Standards Institute) (2010; 2012). Antimicrobial activity assays were performed using $K$. pneumoniae (ATCC13883) and S. aureus (ATCC25923). For each assay, chloramphenicol $(30 \mu \mathrm{g} / \mathrm{mL})$ was used as positive control $(\mathrm{C}+)$ and $\mathrm{MH}$ broth at $\mathrm{pH} 7.3$ as a negative control. Bacterial growth was monitored every $30 \mathrm{~min}$ until it reached the stationary phase (about $24 \mathrm{~h}$ ). The protein fractions 16-22 were utilized in a concentration of $120 \mu \mathrm{g} / \mathrm{mL}$. Percentage of bacterial growth inhibition values was based on the absorbency values at $625 \mathrm{~nm}$, which were compared with the values obtained for $\mathrm{C}+$ (representing $100 \%$ bacterial growth inhibition). All antibacterial assays were performed in triplicate.

\section{Results}

\section{Production of clavMO}

$\mathrm{X}-33 / \mathrm{pPICZ} \alpha \mathrm{A}$-clavMO and X-33/pGAPZ $\alpha \mathrm{B}$-clavMO were selected for growth experiments and heterologous peptide production. $P$. pastoris containing the constitutive expression cassette, pGAPZ $\alpha B$-clavMO, resulted in about 1.5-fold lower final OD when compared to the strain containing the inducible expression cassette pPICZ $\alpha \mathrm{A}$-clavMO (Figure 2). Therefore for the evaluation of antibacterial activity of clavMO the strain pPICZ $\alpha A$-clavMO was chosen.

\section{Analysis of recombinant clavMO by Western blot}

Supernatant of the strains X33/pPICZ $\alpha \mathrm{A}$-clavMO and $\mathrm{X} 33 / \mathrm{pGAPZ} \alpha \mathrm{B}$-clavMO were collected at 0, 24, 48 and $70 \mathrm{~h}$. Samples of $150 \mu \mathrm{g} / \mathrm{mL}$ from supernatant from the culture were applied into an SDS-PAGE (12\%) prior

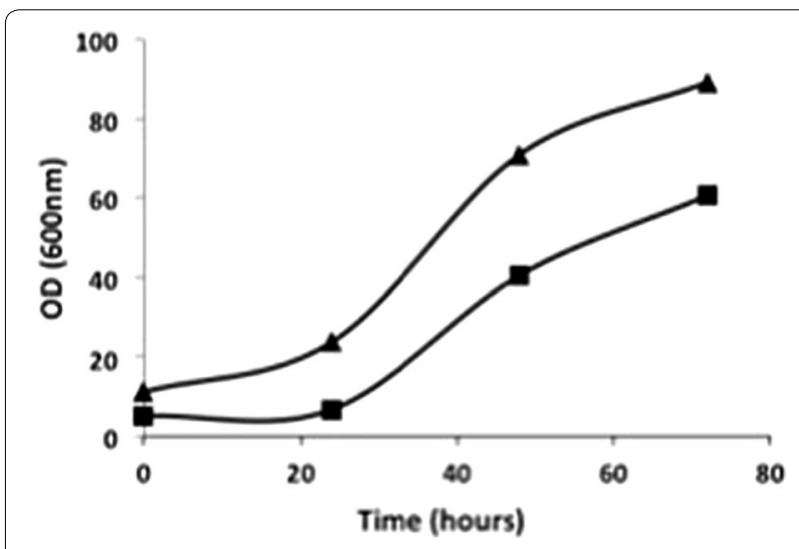

Figure 2 Growth of P. pastoris strains X33/pPICZ $\alpha A$-clavMO $\left(\mathrm{P}_{\mathrm{AOX}}\right.$, triangle) and X33/pGAPZ $\alpha B$-clavMO ( $P_{G A P}$, square). Growth was monitored by $\mathrm{OD}_{600}$ every $24 \mathrm{~h}$. Methanol (0.5\%) was added to P. pastoris strain X33/pPICZ $\alpha$ A-clavMO after 30 h of growth. Experiments were done in triplicate where figure shows the growth profile within $10 \%$ standard deviation.

Western blot assay. According to the results obtained, it can be observed that the expression of the recombinant clavMO was detected at 48 and $70 \mathrm{~h}$ in both strains while no recombinant protein was detected prior induction with Methanol (Figure 3). It was also observed that the appropriated time for induction of the promoter AOX1 in the X33/pPICZ $\alpha \mathrm{A}$-clavMO strain was after $30 \mathrm{~h}$ when all initial glycerol was entirely consumed (Figure 3, lower panel), as well as the constitutive expression of the promoter $\mathrm{P}_{\mathrm{GAP}}$ for production of the recombinant clavMO in the X33/pGAPZ $\alpha$ B-clavMO strain (Figure 3, upper panel). The predicted size of Thioredoxin-ClavMO fused gene was $34.47717 \mathrm{kDa}$ (http://web.expasy.org/compute_ $\mathrm{pi} /$ ). Our Western blot results show that the detected protein correspondent to our expression cassette was between 35 and $40 \mathrm{kda}$ (Figure 3), therefore, bigger than the predicted MW.

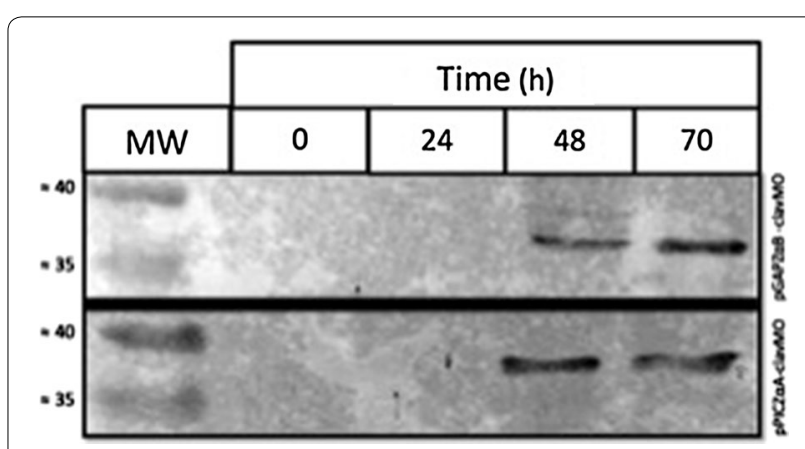

Figure 3 Western blot assay of the supernatant of the strains X33/ pGAPZaB-clavMO (upper panel) X33/pPICZ $\alpha$ A-clavMO (lower panel). Samples were collected at times 0,24, 48 and 70 h. MW molecular weight ( $\mathrm{kD}$ ). Antibody anti-his tag 1:5,000 


\section{Purification}

Figure 4 shows the profile of the $P$. pastoris supernatant containing X33/pPICZ $\alpha \mathrm{A}$-clavMO after $70 \mathrm{~h}$ of cultivation. From purification of $5 \mathrm{mg} / \mathrm{mL}$ of protein extract into a size exclusion chromatography, seven fractions were collected, numbered 16-22, and were selected for further analysis. After lyophilization, these samples were used to perform antibacterial assays, and two fractions, 21 and 22, were shown to have antibacterial activity. SDS-PAGE analyses of theses samples had shown the protein band corresponding to the molecular mass of clavMO but with different purity degrees (Figure 4).

\section{Antibacterial assays}

Preliminary bioassays revealed that some fractions showed low protein quantification and no antibacterial activity. Therefore, the fractions ranging from 16 to 22 were chosen for antibacterial bioassay due to their higher absorbance at $280 \mathrm{~nm}$. Bioassays were performed against Gram-negative $K$. pneumoniae and Gram-positive $S$. aureus bacteria. For each bioassay, $120 \mu \mathrm{g} / \mathrm{mL}$ of X-33/ pPic-clavMO protein was used in triplicate. The bioassay against $K$. pneumoniae showed antibacterial activity for fraction 21 and 22 where bacterial growth was reduced by 56 and $8 \%$, respectively (Table 2 ). On the other hand, the bioassay performed against $S$. aureus showed antibacterial activity for fractions 21 and 22 where bacterial growth was inhibited by 68 and $89 \%$, respectively (Table 2).

\section{Discussion}

Heterologous production of antimicrobial peptides has been attempted in several hosts over the last few years.
Table 2 Antibacterial assay against $K$. pneumoniae and $S$. aureus using $120 \mu \mathrm{g} / \mathrm{mL}$ of X-33/pPic-clavMO protein for $24 \mathrm{~h}$ at absorbance $\lambda=625 \mathrm{~nm}$

\begin{tabular}{lll}
\hline $\begin{array}{l}\text { Antibacterial activity (\%) } \\
\begin{array}{l}\text { Fractions X-33/pPic- } \\
\text { clavMO }\end{array}\end{array}$ & $\begin{array}{l}\text { Klebsiella pneumo- } \\
\text { niae (ATCC13883) }\end{array}$ & $\begin{array}{l}\text { Staphylococcus } \\
\text { aureus (ATCC25923) }\end{array}$ \\
\hline 16 & NS & NS \\
17 & NS & NS \\
18 & NS & NS \\
19 & NS & NS \\
20 & NS & NS \\
21 & $56 \pm 1.4$ & $68 \pm 1.7$ \\
22 & $8 \pm 1.2$ & $89 \pm 1.4$ \\
\hline
\end{tabular}

Values were represented by mean \pm standard deviation. Chloramphenicol $(30 \mu \mathrm{g} / \mathrm{mL})$ and $\mathrm{MH}$ broth, $\mathrm{pH}: 7.3$, as positive and negative controls, respectively.

NS not significant.

After the bacterium Escherichia coli, yeasts are the second most used system for heterologous peptide production (Parachin et al. 2012). In this study, heterologous production of a modified clavanin fused to thioredoxin, clavMO-thio, was initially attempted in different E. coli strains. Nevertheless, expression of the encoding gene could never be confirmed (Additional file 2: Figure S2, Additional file 3: Figure S3 and Additional file 4: Figure S4). The same has been previously observed when the production of SPE10 isolated from the Pachyrrhizus erosus peptide was attempted in both $E$. coli and $P$. pastoris where heterologous peptide production could only be confirmed when produced in yeast (Song et al. 2005).

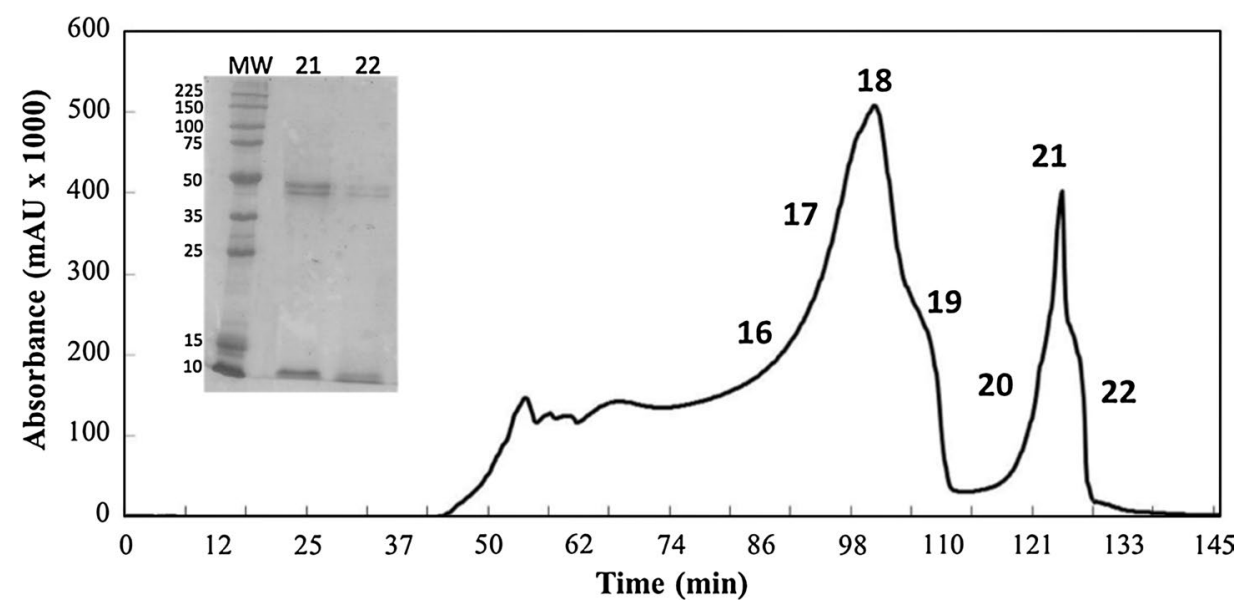

Figure 4 Chromatogram profile of supernatant of strain X-33/pPic-clavMO. $5 \mathrm{mg} / \mathrm{mL}$ of protein extract using a Hiload ${ }^{\mathrm{TM}} 16 / 60$ Superdex $^{\mathrm{TM}} 75 \mathrm{prep}$ grade column (GE Healthcare) originating 24 fractions eluted in approximately $5 \mathrm{~mL}$ and monitored at $280 \mathrm{~nm}$. The silver-stained gel shows the protein recovered from fractions 21 and 22 after purification process. MW molecular weight (kD). 
Although Sacharomyces cerevisiae is the most common yeast utilized for biopharmaceutical production, the yeast $P$. pastoris was chosen as the host in this study for having a GRAS (Generally Regards As Safe) status, the ability to grow in high cell density cultures (since it does not present fermentative behavior), and its reported high levels of secreted recombinant protein, which simplifies downstream purification processes (Ahmad et al. 2014). Finally, most recombinant AMPs produced in yeast use $P$. pastoris as a host (Parachin et al. 2012).

Although some companies claim the production of recombinant clavanins isoforms such as B, C, D and E using both $S$. cerevisiae and $E$. coli as hosts, herein we report for the first time the heterologous production of clavanin using $P$. pastoris as a host to express clavMO. Synthetic ClavMO is reported to have higher antibacterial activity against both Gram-positive (e.g., $78.75 \mu \mathrm{M}$ against $S$. aureus ATCC29213; 2.5-fold higher than synthetic clavA) and Gram-negative bacteria (e.g. $39.40 \mu \mathrm{M}$ against $K$. pneumoniae-ATCC13885; 2.5-fold higher than synthetic clavA). Furthermore, clavMO has also presented immunomodulatory, antitumor, antiviral and insecticide activities (Silva et al. 2011b).

In this study Clav-MO fused to thioredoxin in its $\mathrm{N}$-terminal presented antibacterial activity. Although one could argue that thioredoxin could have inhibitory activity by itself its gene sequence was from the $E$. coli genome where it has been previously described its role in defense against oxidative stress or in control of apoptosis (Arnér and Holgren 2000). Moreover thioredoxin is frequently used as a carrier protein for production of recombinant antimicrobial peptide representing more than $20 \%$ of all reported fusion expressions of antimicrobial peptides (Li 2009). Finally, in a study for heterologous production of viscotoxin where 13 fusion proteins were tested, thioredoxin gave the highest yield of soluble protein (Bogomolovas et al. 2009). For all those reasons we claimed that the activity against the microorganisms tested in our work is derived from the activity of the peptide clav-MO.

Here we demonstrate the production of a heterologous AMP using both constitutive and inducible promoters. Few of the reported studies used a constitutive promoter to express gene encoding for AMPs (Guo et al. 2012; Hong et al. 2007; Yu et al. 2010). Constitutive AMP production is advantageous as the fermentation process is facilitated because there is no need for additional inductor or media exchange. Nevertheless, if the AMP has antifungal activity, the use of such a promoter is not advisable, for it impairs yeast growth and consequently heterologous AMP production. In all reported cases, the amount of heterologous peptide produced using constitutive promoter was not reported. Moreover, in this study the strain with constitutive cassette had a negative impact on final OD, which corroborates previous studies and reinforces the utilization of inducible constructions for heterologous production of AMP.

Regarding clavanin mode of action, it is known that its bactericide activity is related to membrane stability in a pH dependent form (van Kan et al. 2001, 2002, 2003a). Furthermore, clavanin A has been shown to interact with lipid bi-layers, resulting in drastic changes in membrane morphology (van Kan et al. 2003b). Recently, our group has shown that nanoformulated clavanin A inhibit bacterial growth of S. aureus, K. pneumoniae and Pseudonomas aeruginosa, being an excellent candidate for treating patients contaminated with antibiotic-resistant bacteria (Saúde et al. 2014). Another work form our group has shown that clavanin A is effective in treatments of wound and sepsis infections by avoiding the beginning of sepsis, and as consequence, it reduces mortality (Silva et al. 2015).

Nevertheless, the chemical synthesis of clavanin aiming at nanoformulation is not cost-effective. In this study, recombinant clavMO was shown to inhibit both Grampositive and Gram-negative bacteria. Thus, it presents an initial step for the development of cost-effective, largescale production of this AMP.

In this study, for the first time, the modified version of clavanin A, clavMO was heterologously produced in $P$. pastoris using both constitutive and inducible expression cassettes. Both systems yielded protein detection in yeast supernatant by Western blot assays. The strain with integrated constitutive construction resulted in lower final OD when compared to the strain with the inducible construction integrated in its genome. Therefore, the strain producing clavMO after induction with metanol was chosen for the following experiments. ClavMO was produced in a $5 \mathrm{~L}$ scale followed up by purification using gel filtration. Finally, antimicrobial assays showed that recombinant clavMO could inhibit up to 56 and $89 \%$ Gram-negative and Gram-positive bacteria, respectively. Conclusively, it is evident that $P$. pastoris is an excellent host for the functional production of clavMO, and that this system may be utilized for further scale-up production of AMPs. 


\section{Additional files}

Additional file 1: Figure S1. DNA nucleotide sequence for thioredoxin and clavMo (underlined). Start codons of both carrier and peptide sequence are indicated in bold. Stop codon is highlighted in red

Additional file 2: Figure S2. A) Expression vector pET21a(+) used as backbone to insert the expression cassette; B) Expression cassette comprised of a signal sequence (Ss), a HIS-tag, the thioredoxin gene end the ClavMO peptide. In the white boxes are presented the restriction sites

Additional file 3: Figure S3. Western blot analysis of the supernatant fraction of lysed E. coli strains. A) pLyzS/pET21-clavMO, B) pRIL/ pET21-clavMO

Additional file 4: Figure S4. Western blot analysis of the pellet cell fraction of lysed E. coli strains. A) pLyzS/pET21-clavMO, B) pRIL/pET21-clavMO

\section{Abbreviations}

AMP: antimicrobial peptide; ClavMO: clavanin modified; ClavA: clavanina A: AOX1: alcohol oxidase l; GAP: glyceraldehyde-3-phosphate dehydrogenase.

\section{Authors' contributions}

All authors have equally contributed to this work and have read and approved the final manuscript.

\begin{abstract}
Author details
${ }^{1}$ Centro de Análises Proteômicas e Bioquímicas, Pós-Graduação em Ciências Genômicas e Biotecnologia, Universidade Católica de Brasília, Brasília, DF, Brazil. ${ }^{2}$ Grupo Engenharia de Biocatalisadores, Departamento de Biologia Celular, Instituto de Ciências Biológicas, Universidade de Brasília, Brasília, DF CEP 70.790-900, Brazil. ${ }^{3}$ S-Inova, Pós-Graduação em Biotecnologia, Universidade Católica Dom Bosco, Campo Grande, MS, Brazil.
\end{abstract}

\section{Acknowledgements}

The National Counsel of Technological and Scientific Development (CNPq), the Coordination for the Improvement of Educational Personnel (CAPES), the Foundation for Research Support of the Federal District (FAPDF), the Foundation for Educational, Research and Technology of Mato Grosso do Sul (FUN$\mathrm{DECT}$ ), and the Ministry of Science and Technology (MCT) are acknowledged for financial support.

\section{Compliance with ethical guidelines}

\section{Competing interests}

The authors declare that they have no competing interests.

Received: 1 June 2015 Accepted: 7 July 2015

Published online: 06 August 2015

\section{References}

Agyei D, Danquah MK (2011) Industrial-scale manufacturing of pharmaceutical-grade bioactive peptides. Biotechnol Adv 29(3):272-277

Ahmad M, Hirz M, Pichler H, Schwab H (2014) Protein expression in Pichia pastoris: recent achievements and perspectives for heterologous protein production. Appl Microbiol Biotechnol 98(2):5301-5317

Arnér ES, Holgren A (2000) Physiological functions of thioredoxin and thioredoxin reductase. Eur J Biochem 267(20):6102-6109

Basanta A, Gómez-Sala B, Sánchez J, Diep DB, Herranz C, Hernández PE et al (2010) Use of the yeast Pichia pastoris as an expression host for secretion of enterocin L50, a leaderless two-peptide (L50A and L50B) bacteriocin from Enterococcus faecium L50. Appl Environ Microbio 76(10):3314-33124

Blum H, Beier H, Gross HJ (1987) Improved silver staining of plant-proteins, RNA and DNA in polyacrylamide gels. Electrophoresis 8(2):93-99

Bogomolovas J, Simon B, Sattler M, Stier G (2009) Screening of fusion partners for high yield expression and purification of bioactive viscotoxins. Protein Expr Purif 64(1):16-23
Cabral KM, Almeida MS, Valente AP, Almeida FC, Kurtenbach E (2003) Production of the active antifungal Pisum sativum defensin 1 (Psd1) in Pichia pastoris: overcoming the inefficiency of the STE13 protease. Protein Expr Purif 31(1):115-122

De Schutter K, Lin YC, Tiels P, Van Hecke A, Glinka S, Weber-Lehmann J et al (2009) Genome sequence of the recombinant protein production host Pichia pastoris. Nat Biotechnol 27(6):561-566

Ellis SB, Brust PF, Koutz PJ, Waters AF, Harpold MM, Gingeras TR (1985) Isolation of alcohol oxidase and two other methanol regulatable genes from the yeast Pichia pastoris. Mol Cell Biol 5(5):1111-1121

Esposito D, Chatterjee DK (2006) Enhancement of soluble protein expression through the use of fusion tags. Curr Opin Biotechnol 17(4):353-358

Guo C, Huang Y, Zheng H, Tang L, He J, Xiang L et al (2012) Secretion and activity of antimicrobial peptide cecropin D expressed in Pichia pastoris. Exp Ther Med 4(6):1063-1068

Hong IP, Lee SJ, Kim YS, Choi SG (2007) Recombinant expression of human cathelicidin (hCAP18/LL-37) in Pichia pastoris. Biotechnol Lett 29(1):73-78

Jimenez JJ, Borrero J, Gutiez L, Arbulu S, Herranz C, Cintas LM et al (2014) Use of synthetic genes for cloning, production and functional expression of the bacteriocins enterocin A and bacteriocin E 50-52 by Pichia pastoris and Kluyveromyces lactis. Mol Biotechnol 56:571-583

Kant P, Liu WZ, Pauls KP (2009) PDC1, a corn defensin peptide expressed in Escherichia coli and Pichia pastoris inhibits growth of Fusarium graminearum. Peptides 30(9):1593-1599

Kim SJ, Quan R, Lee SJ, Lee HK, Choi JK (2009) Antibacterial activity of recombinant hCAP18/LL37 protein secreted from Pichia pastoris. J Microbiol 47(3):358-362

Laemmli UK (1970) Cleavage of structural proteins during the assembly of the head of bacteriophage T4. Nature 227(5259):680-685

Li Y (2009) Carrier proteins for fusion expression of antimicrobial peptides in Escherichia coli. Biotechnol Appl Biochem 54(1):1-9

Mattanovich D, Callewaert N, Rouzé P, Lin Y-C, Graf A, Redl A et al (2009) Open access to sequence: browsing the Pichia pastoris genome. Microb Cell Fact 8:53

Mulder KCL, Lima LA, Miranda VJ, Dias SC, Franco OL (2013a) Current scenario of peptide-based drugs: the key roles of cationic antitumor and antiviral peptides. Front Microbiol 4:321

Mulder KCL, Viana AAB, Xavier X, Parachin NS (2013b) Critical Aspects to be considered prior to Large-Scale Production of peptides. Curr Protein Pept Sci 14:556-567

Parachin NS, Mulder KC, Viana AA, Dias SC, Franco OL (2012) Expression systems for heterologous production of antimicrobial peptides. Peptides 38(2):446-456

Saúde AC, Ombredane AS, Silva ON, Barbosa JA, Moreno SE, Araujo AC et al (2014) Clavanin bacterial sepsis control using a novel methacrylate nanocarrier. Int J Nanomed 9:5055-5069

Silva ON, Mulder KC, Barbosa AE, Otero-Gonzalez AJ, Lopez-Abarrategui C, Rezende TM et al (2011) Exploring the pharmacological potential of promiscuous host-defense peptides: from natural screenings to biotechnological applications. Front Microbiol 2:232

Silva ON, Migliolo L, Dias SC, Rezende TMB, Franco, OL (2011b) Patent: Antimicrobial, insecticide and antitumor synthetic molecule, composition use and microorganism inhibition method. INPI, Brazil Patent Number 0000221109717908

Silva ON, Fensterseifer ICM, Rodrigues EA, Holanda HHS, Novaes NRF, Cunha JPA et al (2015) Clavanin A improves outcome of complications from different bacterial infections. Antimicrob Agents Chemother 59(3):1620-1626

Song X, Wang J, Wu F, Li X, Teng M, Gong W (2005) cDNA cloning, functional expression and antifungal activities of a dimeric plant defensin SPE10 from Pachyrrhizus erosus seeds. Plant Mol Biol 57(1):13-20

Tang XS, Tang ZR, Wang SP, Feng ZM, Zhou D, Li TJ et al (2012) Expression, purification, and antibacterial activity of bovine lactoferrampin-lactoferricin in Pichia pastoris. Appl Biochem Biotech 166(3):640-651

Towbin H, Staehelin T, Gordo J (1979) Electrophoretic transfer of proteins from polyacrylamide gels to nitrocellulose sheets: procedure and some applications. Biotechnol Adv 24:145-149

van Kan EJ, van der Bent A, Demel RA, de Kruijff B (2001) Membrane activity of the peptide antibiotic clavanin and the importance of its glycine residues. Biochemistry 40(21):6398-6405 
van Kan EJ, Demel RA, Breukink E, van der Bent A, de Kruijff B (2002) Clavanin permeabilizes target membranes via two distinctly different $\mathrm{pH}$-dependent mechanisms. Biochemistry 41(24):7529-7539

van Kan EJ, Demel RA, van der Bent A, de Kruijff B (2003a) The role of the abundant phenylalanines in the mode of action of the antimicrobia peptide clavanin. Biochim Biophys Acta Protein Struct Mol Enzymol 1615(1-2):84-92

van Kan EJ, Ganchev DN, Snel MM, Chupin V, van der Bent A, de Kruijff B (2003b) The peptide antibiotic clavanin A interacts strongly and specifically with lipid bilayers. Biochemistry 42(38):11366-11372

Varnai A, Tang C, Bengtsson O, Atterton A, Mathiesen G, Eijsink VG (2014) Expression of endoglucanases in Pichia pastoris under control of the GAP promoter. Microb Cell Fact 13(1):57

Viragh M, Voros D, Kele Z, Kovacs L, Fizil A, Lakatos G et al (2014) Production of a defensin-like antifungal protein NFAP from Neosartorya fischeri in Pichia pastoris and its antifungal activity against filamentous fungal isolates from human infections. Protein Expr Purif 94:79-84

Waterham HR, Digan ME, Koutz PJ, Lair SV, Cregg JM (1997) Isolation of the Pichia pastoris glyceraldehyde-3-phosphate dehydrogenase gene and regulation and use of its promoter. Gene 186(1):37-44

Yu R, Dong S, Zhu Y, Jin H, Gao M, Duan Z et al (2010) Effective and stable porcine interferon-alpha production by Pichia pastoris fed-batch cultivation with multi-variables clustering and analysis. Bioprocess Biosyst Eng 33(4):473-483

Zhang AL, Luo JX, Zhang TY, Pan YW, Tan YH, Fu CY et al (2009) Recent advances on the GAP promoter derived expression system of Pichia pastoris. Mol Biol Rep 36(6):1611-1619

Zhao P, Cao G (2012) Production of bioactive sheep beta-defensin-1 in Pichia pastoris. J Ind Microbiol Biotechnol 39(1):11-17

\section{Submit your manuscript to a SpringerOpen ${ }^{\odot}$ journal and benefit from:}

- Convenient online submission

- Rigorous peer review

- Immediate publication on acceptance

- Open access: articles freely available online

- High visibility within the field

- Retaining the copyright to your article

Submit your next manuscript at $>$ springeropen.com 